Article

\title{
The Project-Based Firm: A Theoretical Framework for Building Dynamic Capabilities
}

\author{
Víctor Hermano *(D) and Natalia Martín-Cruz \\ Department of Business Organization and Marketing and Market Research, University of Valladolid, Avda Valle \\ Esgueva 6, 47011 Valladolid, Spain; ambiela@eco.uva.es \\ * Correspondence: victor.hermano@uva.es; Tel.: +34-983-184-560
}

Received: 28 July 2020; Accepted: 13 August 2020; Published: 17 August 2020

\begin{abstract}
The problem of achieving individual project performance has been replaced by the problem of achieving organizational goals through project performance. Only project-based firms able to learn and build project capabilities can successfully compete in today's dynamic environments. The purpose of this paper is to present a dynamic capability-based framework that sheds light on how project and organizational dynamic capabilities are built and how these dynamic capabilities allow project-based firms to perform in dynamic environments. Our theoretical framework unpacks the processes of building dynamic capabilities inside a project-based firm, discussing the routines and procedures that are useful to manage projects in unstable and dynamic environments and to build and reconfigure organizational capabilities from project-led knowledge.
\end{abstract}

Keywords: routines; organizational performance; project knowledge; portfolio management

\section{Introduction}

Project management literature posits that project-based firms (PBFs) achieve superior performance in dynamic environments [1,2]. Specifically, the literature on PBFs posits that, given their special features (i.e., flexible and innovative nature, ability to respond to environmental changes), PBFs constitute an ideal organizational form to compete in industries where uncertainty, product complexity, and environmental changes are pervasive elements [1-4].

To offer a theoretical explanation for the better performance of PBFs in dynamic environments, project management scholars have adopted a capabilities approach $[5,6]$, and the research on PBFs has focused on project capabilities. Project capability development is the key factor for achieving PBF success through multiple project implementation [7]. Project capabilities are a special type of organizational capability that help PBFs to develop activities of pre-bid, bid preparation, and project execution, providing the firm with "economies of repetition" [7]. However, little research focuses on building project capabilities or their influence on PBF performance, but have researchers studied the relationship between project capabilities and other PBF elements, such as project management assets [8], or their impact on portfolio management and results [9]. Moreover, the project capability literature takes a supplier perspective that focuses on firms that supply their projects to other firms, thus considering just commercial (pre-bid, bid, and offer) capabilities and project coordination capabilities [10].

To fill the gap, we build a dynamic capability-based framework for PBFs that sheds light on the research questions of (a) how project and organizational dynamic capabilities are built and (b) how these dynamic capabilities allow PBFs to perform in turbulent environments by addressing environmental changes. We posit that PBFs can address environmental changes by building project dynamic capabilities. Based on Winter [11] (p. 991), we define a project capability as a high-level routine (or collection of routines) that, together with its implemented input flows, confers upon a PBF's management a set of decision options for producing project deliverables and goals. A project 
dynamic capability is formed by reconfiguring project assets and project management processes in the manner envisioned by the project managers (based on [12] (p. 918)). Therefore, we claim that, to reach overall organizational goals, PBFs should build organizational structures and processes that foster learning and knowledge-sharing both between projects and the permanent organization. A PBF's long-term performance is achieved by developing both project dynamic capabilities but also organizational dynamic capabilities.

The remainder of the paper is structured as follows. Section 2 provides a literature review on PBFs. Section 3 presents our theoretical framework for building project and organizational dynamic capabilities. Finally, in Section 4, we discuss the main implications and conclusions of the theoretical framework.

\section{Theoretical Background}

\subsection{The Project-Based Firm}

Project management research has evolved from a normative ontology whose focus was on optimizing project management tools and techniques to assure project success, into a wider perspective, assuming that the study of projects in isolation has to be at least accompanied by the study of strategic and organizational issues [13,14].

Therefore, the focus on project management research has shifted from a project-centric approach to a wider strategic and organizational approach, and studies on PBFs have become a relevant literature stream. However, although profusely cited, the notion of PBFs is not without controversy as no commonly accepted definition for PBFs exists. Table 1 provides a sampling of definitions from the literature that, although very different in their wording, can be grouped around four powerful ideas: (a) the PBF definitions from Tikannen, Kujala, and Artto [15] and Turner and Keegan [16] emphasize that PBFs deliver projects to external customers; (b) the PBF definitions from Di Vincenso and Mascia [17], Lindkvist [18], Melkonian and Picq [1], Hobday [4], and Turkulainen et al. [19] emphasize that PBFs focus on projects as the main mechanism for developing their business and activities; (c) the PBF definitions from Hobday [4], Söderlund and Tell [20], and Whitley [21] emphasize that PBFs build specific project routines and capabilities; and, finally, (d) the PBF definitions from Gareis [22] and Thiry and Deguire [2] emphasize that PBFs develop specific project-based structures and constitute an organizational form.

For the purpose of this paper, we propose a definition of PBFs that establishes the competences of PBFs as the cornerstone. Therefore, PBF research should focus on how to achieve organizational strategic goals through multiple projects and portfolio implementation [1,2,7]. Specifically, PBFs must build permanent structures, allowing the firm to cope with problems that arise during the implementation of different projects [23] and to align those projects with the overall strategy [1,24]. Therefore, we define a PBF as an organization in which project capabilities shape not only project management processes but also all internal and external competences of the organization. Being project-based means that the project lessons learned influence daily work operations; hence, project learning is spread across the whole organization. Specifically, previous PBF literature has shown the role projects play in organizational issues, such as discovering and assessing new market opportunities [25], developing new products and processes [26], exploring new technologies [27], generating new business models [28], renewing organizational strategy [29], etc. Moreover, being project-based implies understanding projects as a means for strategy implementation and strategy redefinition. Thus, we argue that the key point of being a PBF is the capacity to build and shape organizational capabilities through project processes and to consolidate and spread project learning, regardless of the internal organizational structure (matrix, functional, or adhocracy), the number of activities developed through projects, and the purpose of the projects. 
Table 1. Definitions of project-based firms (PBFs).

\begin{tabular}{|c|c|}
\hline Definitions by Direct Quote and Reference & Key Concept \\
\hline $\begin{array}{c}\text { A project-based firm uses external delivery projects for its business purposes [15] (p. 194) } \\
\text { A project-based organization as a stand-alone entity that makes products for external customers, or a subsidiary of a business unit of } \\
\text { a larger firm that makes products for internal or external customers [16] (p. 132) }\end{array}$ & PBFs deliver projects to external customers \\
\hline $\begin{array}{l}\text { Firms that privilege strongly the project dimension and carry out most of their activities in projects may generally be referred to as } \\
\text { project-based firms [18] (p. 5) } \\
\text { The terminology of PBO includes all the organizations that carry out their core operations mainly or even exclusively in project form. } \\
\text { In PBOs, projects are the dominant form of activity, value creation and sources of revenues [1] (p. 456) } \\
\text { This means that "project-based firms", referring to firms conducting business mainly by projects, face new challenges in designing } \\
\text { their organizations [19] (p. 221) } \\
\text { The PBO is one in which the project is the primary unit for production organisation, innovation, and competition. Within a PBO the } \\
\text { project is the primary business mechanism for coordinating and integrating all the main business functions of the firm [4] (p. 874) }\end{array}$ & $\begin{array}{c}\text { Projects as the main mechanism for developing their business } \\
\text { and activities }\end{array}$ \\
\hline $\begin{array}{l}\text { The PBO is one in which the project is the primary unit for production organisation, innovation, and competition. In the PBO, } \\
\text { knowledge, capabilities, and resources of the firm are built up through the execution of major projects [4] (p. 874) } \\
\text { P-form organizations operate projects on a repetitive basis; they develop routines and deep knowledge to handle complex and } \\
\text { difficult problems and projects. The characteristics of the P-form organization that we believe are particularly important in the } \\
\text { analysis of associated organizational capabilities. We also include a few classic contingency dimensions common in organization } \\
\text { theory as well as knowledge processes and communication types discussed by Hedlund [20] (p. 102) } \\
\text { PBFs are legally constituted collective actors that control property rights and exercise formal authority over task organization and } \\
\text { performance through employment contracts. Some types are able to develop firm-specific capabilities and knowledge through the } \\
\text { management of a succession of projects and employment of skilled staff [21] (pp. 79-80) }\end{array}$ & PBFs build specific project routines and capabilities \\
\hline $\begin{array}{l}\text { The '"new" project-oriented company can be defined as a company that carries out small and large projects, internal and external } \\
\text { projects, and unique and repetitive projects, simultaneously. It has a specific (project-oriented) structure and culture to manage its } \\
\text { single projects and its network of projects, and it applies a variety of project-management methods that are appropriate to different } \\
\text { project situations [22] (p. 72) } \\
\text { Project-based organisations (PBO) refer to a variety of organisational forms that involve the creation of temporary systems for the } \\
\text { performance of project tasks [2] (p. 649) }\end{array}$ & PBFs constitute an organizational form \\
\hline
\end{tabular}




\subsection{Capabilities Approach to Project-Based Firms}

With few exceptions [23,30-34], previous research has emphasized the problems that PBFs face when trying to learn from previous projects and to spread that knowledge throughout the whole organization $[4,35,36]$.

In order to address learning problems, PBFs should develop project capabilities [7]. The initial conception of project capabilities refers to the specific knowledge and experience required to engage with customers, develop bid offers, and implement projects $[7,25]$. These project capabilities arise through two interacting levels of learning, the first level describing bottom-up learning that starts with the implementation of a vanguard project that requires novel activities, and the second level describing the business-led learning that occurs when a new line of business is established based on the novel project that was previously implemented [7]. From this conception, researchers have worked in two main streams of empirical research on project capabilities: (a) research focused on the relationship between project capabilities and other elements of PBFs and (b) research focused on the impact of project capabilities on portfolio performance. Regarding the first stream of literature, Jugdev and Thomas [37] and Lee and Anderson [38] analyze the role played by maturity models in project capability formation. Moreover, Jugdev, Mathur, and Fung [8] study the project management assets supporting project capabilities, finding that intangible project management assets, such as sharing know-how or tacit knowledge, provide a temporary competitive advantage, whereas tangible project management assets, such as project management tools and techniques, databases, methodologies, and standards, do not. Regarding the second stream of literature, Hermano and Martín-Cruz [39] and Petit [9] study project capabilities within an environment of high uncertainty, showing that project dynamic capabilities help PBFs to manage project portfolios in dynamic environments. Biedenbach and Müller [40] examine the effects of absorptive, innovative, and adaptive capabilities on short- and long-term project performance and portfolio performance.

In order to reinforce and improve their original model, Davies and Brady [41] incorporate a dynamic approach by connecting project capabilities to ambidexterity and dynamic capability concepts. Specifically, they claim that the bottom-up learning phase in capability formation involves the implementation of exploration activities and the business-led learning phase involves the implementation of exploitation activities [41]. Moreover, given the dynamic and learning essence of the dynamic capabilities approach, several researchers have recently enacted the cross-fertilization between project management and the dynamic capabilities approach as a very potential research stream [40,42-45].

Another stream of research that might strengthen the theoretical foundations of the project capabilities approach is the one focused on the absorptive capacity of firms. Absorptive capacity is the ability of firms to recognize and exploit knowledge flows [46]. Specifically, knowledge creation depends on the firm's absorptive capacity and its enablers, such us knowledge stock, people, and products [46]. Recently, some scholars have identified absorptive capacity as a dynamic capability that embraces four dimensions (i.e., the identification of external knowledge, the assimilation of external knowledge, transformation, and exploitation) [47], finding that it is positively related to product innovation, portfolio performance, better decision making, and even the acquisition of competitive advantages $[40,46,48]$.

\section{A Dynamic Capabilities Framework for Project-Based Firms}

Several models on how to build and reconfigure dynamic capabilities have been proposed. For the purpose of this paper, we adopt Teece's $[49,50]$ framework, which provides relevant insights to the building and reconfiguration of dynamic capabilities by specifying their nature and general micro-foundations and, specifically, we apply Teece's $[49,50]$ framework to the project management domain. Teece $[49,50]$ disaggregates dynamic capabilities into three groups of general routines: (a) routines to sense opportunities, (b) routines to seize opportunities, and (c) routines to maintain competitiveness by enhancing, combining, and reconfiguring the firm's assets. 
We adopt Teece's [49,50] framework and adapt it to explain project dynamic capabilities of PBFs. Scholars argue that studying specific business processes representing dynamic capabilities is better than composing a comprehensive but vague general dynamic capability [51,52]. Furthermore, studying a specific dynamic capability "sheds light not only on these specific processes but also on the generalized nature of dynamic capabilities" [53]. Therefore, we develop a two-layer framework to explain project dynamic capability building.

As presented in Figure 1, we first introduce the project-layer routines that intend to enhance the performance of projects surrounded by uncertainty and unexpected changes. Then, we introduce the PBF-layer routines that provide the PBFs with mechanisms for consolidating individual project learning and reaching organizational strategic goals through the building and reconfiguration of organization-wide capabilities. Moreover, in line with previous research [54], our framework disaggregates both project and PBF dynamic capabilities into three different groups of routines: those that sense opportunities and threats, those that seize opportunities, and those that maintain competitiveness by reconfiguring organizational capabilities.

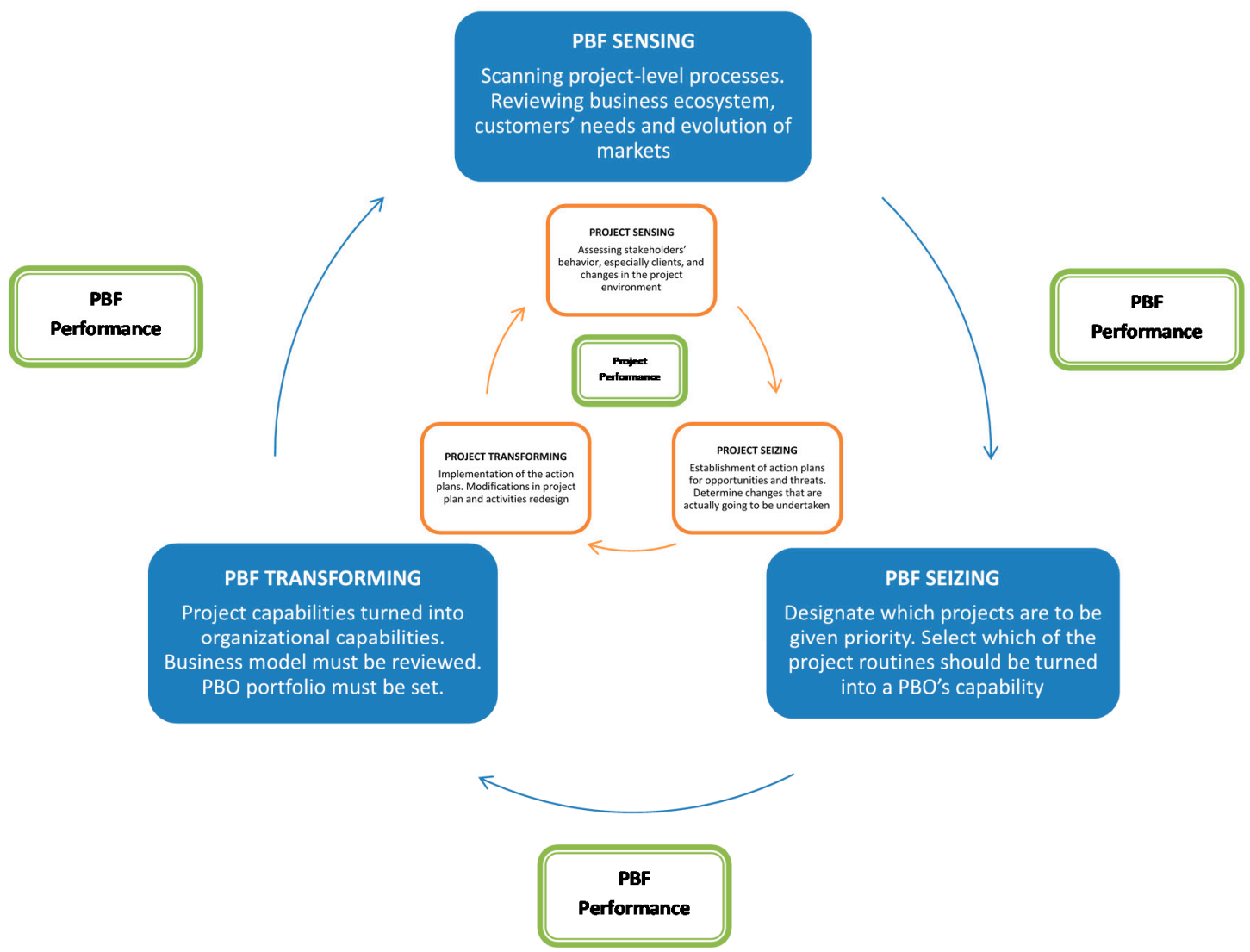

Figure 1. Two layers of dynamic capabilities: PBF and projects.

\subsection{Project-Layer Routines}

At the project layer, the dynamic capabilities framework discusses the project management routines and processes that allow project managers to address environmental and client changes, theoretically leading to higher project performance under conditions of uncertainty [55]. Regarding project-layer routines, sensing mainly implies scanning and interpretative routines. Project-sensing routines allow the project team to detect potential changes within both the project scope and general environment, and to manage stakeholders' behavior, helping them to understand how these variables influence project content and the project managers' decisions [55-57]. Project-sensing routines include, among others, information gathering during the project lifecycle, the adaptation of project management methodology 
to the project environment, the assessment of stakeholders' influence on project performance, and the continual search for environmental changes.

Project-layer seizing implies planning and decision-making routines. Project-seizing routines allow the project team to plan and design how to address an opportunity or threat previously sensed $[50,55]$. On the one hand, the project team assesses the nature and importance of the influence of previously sensed changes over different aspects of the project, such as the project's content, scope, and plan. Then, the project team builds decision-making protocols and governance rules to address the most relevant changes. Project-seizing routines include, among others, establishing a clear definition of a change management policy, the documentation of the impact of change requests, designing action plans for the opportunities and threats detected, and building decision-making protocols and go/kill decisions.

Finally, project-layer transformation routines imply managing threats and reconfiguration $[49,50]$. Routines can become dysfunctional and develop rigidities and inertia that hinder performance [58]. Project-transforming routines allow the project team to implement the needed changes identified by sensing and addressed by seizing [9,55]. As the project proceeds and previously unknown details become known, the project team executes the plans previously defined, thus redesigning project activities and modifying project scope to effectively address the changes previously sensed. Project-transforming routines include, among others, the updating and modification of project plans and documents, updates and changes in the project organization, and the reconfiguration of project capabilities based on changes previously sensed.

\subsection{Project-Based Firm-Layer Routines}

After a project is closed, the knowledge gained is at risk of being lost due to project team dissolution [25]. Unless the lessons learned are properly stored and made available for subsequent projects, the firm also faces the risk of struggling with the same difficulties and making the same mistakes, forcing the PBF to reinvent the wheel [59]. We extend our framework from the project layer to the PBF layer and show how PBFs can use the knowledge gained throughout the project lifecycle to build and reconfigure organizational capabilities. As depicted in Figure 2, the PBF layer explains how project learning can be consolidated and spread throughout both business units and the entire firm. Specifically, project capabilities are sensed and seized in an attempt to determine which of them should be added, totally or partially, to the whole organizational capability endowment in order to improve the performance of organizational functions, such as logistics, marketing and sales, etc. Therefore, the objective of PBF-layer routines is to reconfigure and extend a PBF's capabilities so the firm can fully exploit its project capabilities and reach organizational strategic goals through multiple projects. 


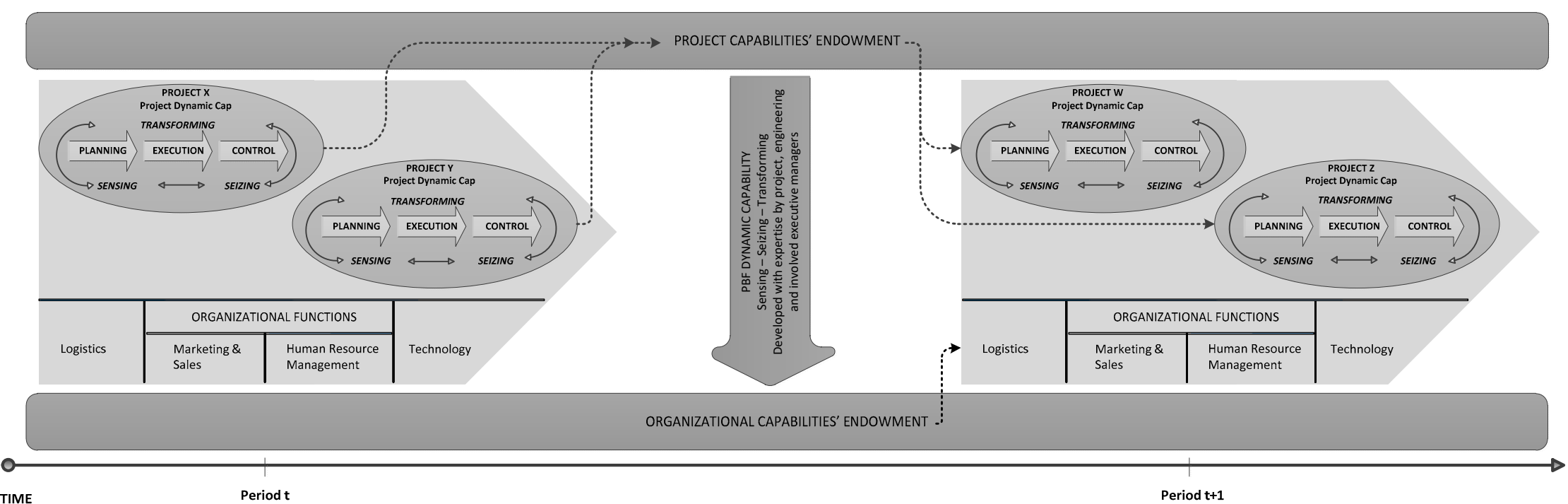

Figure 2. PBF structure through the two-layer framework of building dynamic capabilities. 
Regarding PBF-layer routines, sensing involves scanning the performance of project-layer processes to identify valuable knowledge acquired during project implementation that could be exploited in subsequent projects. Additionally, the PBF environment must be sensed to determine whether the project and PBF capabilities can fulfill future customers' needs. PBF-layer sensing routines allow top and project managers to face the problem of information decay by establishing routines to keep the management team informed about the new trends and competitive actions within the PBF's business ecosystem, the awareness of customers' needs, and the evolution of industries and markets $[49,50]$. PBF-layer sensing routines help the management team to understand how past projects could strength customers' existing relationships, providing new opportunities, such as the creation of new markets or the development of improved business models and technologies [60]. PBF-layer sensing routines include, among others, the application of lessons learned to future projects, the assessment of project capabilities as a means to fulfill future customers' needs, searching for potential clients and future business opportunities, and the assessment of project portfolio composition.

PBF-layer seizing implies deciding which of the sensed options to execute and how and when these options should be deployed [9]. Moreover, PBF-layer seizing involves improving project management competences and then, when the opportunity is ripe, investing heavily in the projects especially suited for the sensed environment [46] (p. 1326). PBF-seizing routines allow the management team to identify which sensed potential projects should be fostered and which should be ignored, which sensed potential markets should be served, and which of the potential clients' needs should be met. Furthermore, PBF-layer seizing helps the management team to decide which of the routines that were run in past and ongoing projects could be exploited in subsequent projects and should be turned into an organizational PBF capability. PBF-layer seizing routines include, among others, establishing criteria for deciding which new projects should join the portfolio and which projects should be dismissed, establishing criteria for deciding which of the new routines should be added to the project management general methodology and which should be dismissed, and establishing criteria for which of the potential new clients should be served and which of them should be ignored.

Finally, PBF-layer transformation routines imply implementing management decisions. Since one key to maintain profitability is the ability to reconfigure assets and routines as markets and environment change, PBF-layer transformation allows the management team to achieve evolutionary fitness and avoid path dependencies [49] (p. 1335). By performing PBF-layer transformation, the project capabilities identified as highly efficient are aligned with the overall organizational capability endowment and turned into organizational capabilities that might be exploited in subsequent projects. PBF-layer transformation helps the management team to avoid falling into the "success trap" [61] by favoring short-term, low-risk "exploitation" projects at the expense of the more long-term, radical "exploration" projects, which are essential to reach organizational strategic goals [44]. PBF-layer transformation routines include, among others, the updating and modification of project portfolio composition, the establishment of a new routine within the project management general methodology, and the updating and modification of business models and PBF strategy.

\section{Concluding Remarks}

\subsection{Discussion}

In today's dynamic environments, a sustainable competitive advantage requires more than the ownership of non-imitable assets [49] (p. 1319). In such environments, the foundations of success depend very little on firms' abilities to optimize or achieve scale economies but, rather, success depends on the discovery and development of opportunities, efficient technology transfer, the upgrading of best practice processes, and the invention of new business models; that is, success depends on the development of dynamic capabilities [49] (p. 1320). However, not all responses to opportunities constitute a dynamic capability; for example, Winter [11] states that ad hoc problem-solving is not a capability. 
This study argues for the necessity of understanding the process of dynamic capability building within a PBF as a way to enhance project and organizational performance in turbulent and dynamic environments. Unlike previous research that examines project and dynamic capabilities, our conceptualization of project and PBF dynamic capabilities establishes theoretical foundations for future research through two main contributions. First, we adapt the dynamic capabilities approach to the project management domain by breaking up the concept of project dynamic capabilities into the specific project routines behind the general sensing, seizing, and transforming groups of routines. Previous studies consider a supplier approach to the study of PBFs and so consider project capabilities as zero-order operative capabilities needed for undertaking unit and small batch production in projects that are tailored to individual customer requirements [7,41]. On the other hand, the prior literature considers portfolio management as a dynamic capability because "it is the process used to implement a firm's top-down strategy through projects" [41] (p. 320). We widen the concept of PBFs to any organization that performs project management processes and embeds project knowledge into the overall organizational memory. Thus, we do not deny that some project management processes belong to the operative level of PBFs' capability endowments for those PBFs applying project management in their day-to-day operations. However, our theoretical framework shows that, even for those suppliers of PBFs, there are some other project management processes clearly deployed for scanning, creating, learning, and interpretative activities (i.e., sensing), for building structures and procedures (i.e., seizing), and for managing threats and reconfiguration (i.e., transforming). Thus, these activities constitute the micro-foundations of a dynamic capability whose outcome is the creation or reconfiguration of the operative project management processes. Second, several studies note that the literature has neglected the role of project capabilities in building and modifying overall organizational strategy and in providing new knowledge for capability reconfiguration $[13,41]$. To fill this gap, our theoretical framework presents two layers of dynamic capabilities within PBFs and discusses the processes performed by executive managers for connecting project and organizational domains. Therefore, we provide an explanation for the linkages between projects and the overall PBF strategy. Moreover, our conceptualization of project and PBF dynamic capabilities provides a theoretical foundation that is lacking in the project management literature. Consequently, we shift the understanding of projects, programs, and portfolios from a practitioner-oriented view to a strategic-oriented one. Identifying project management routines as the micro-foundations for dynamic capabilities helps to explain what processes project and executive managers should deploy to achieve project performance and reconfigure overall PBF capabilities to address environmental shifts.

Moreover, we help to develop a common language for project and strategic management research that the prior literature identifies as important for the advancement of the two disciplines, but is yet unexplored [2]. As illustrated, although projects are still viewed as isolated temporary organizations, they exist within the boundaries of a permanent organization. Therefore, the inter-relationship between permanent PBFs and temporal project organizations are key to explaining PBFs' performances. In addition, we enrich the project management literature by proposing an original definition of PBFs that provides theoretical foundations for the inter-relationship between projects and the $\mathrm{PBF}$, and the nature of that inter-relationship.

Our dynamic capability framework also contributes to literature streams that have approached dynamic capabilities to improve performance in a sustainable mode since it helps to clarify the routines behind building dynamic capabilities, hence facilitating decision-making for those small and medium companies that deploy ecological or sustainable initiatives as a strategy for promoting a new business model [48,62].

\subsection{Limitations}

Although our study identifies the project management processes and routines constituting the micro-foundations of project and PBF dynamic capabilities, it suffers from the following limitations. As with most theoretical frameworks, the dynamic capability approach is not applicable universally 
to every situation and suffers from its own limitations. Therefore, we have to discuss the boundary conditions where the dynamic capability framework of PBFs is applicable. First, as we stated in the presentation of our framework, managers play a key role as the builders of dynamic capabilities. Therefore, in order to properly deploy the different routines comprising project and PBF sensing, seizing, and transforming, we need the management team to behave like experts in their domains.

Another boundary condition revolves around the level of environmental dynamism. Even though there is no general consensus on how the level of environmental dynamism influences the application of the dynamic capability approach [63], several authors claim that, in moderately dynamic environments, dynamic capabilities rely on highly developed and specified routines (as those described in the Project Management Body of Knowledge), while in regimes of rapid change, dynamic capabilities are simple and experiential processes arising from the experience and expertise of managers $[53,63]$.

Finally, another limitation emerges from the fact that the paper is conceptual. The purpose of the paper is to develop a dynamic capability-based framework for PBFs that sheds light on the research questions of (a) how project and organizational dynamic capabilities are built and (b) how these dynamic capabilities allow PBFs to perform in turbulent environments by addressing environmental changes. However, just as in the seminal papers of Teece et al. [64] or Eisenhardt and Martin [53], there is no validation of the framework included in the paper. As a future avenue for research, empirical papers must be developed for testing our theoretical claims. Part of the empirical validation has already started since authors have several empirical working papers covering different parts of the theoretical framework, whose results show that PBFs running the sensing-seizing-transforming routines, such as the adaptation of project management methodology to the project environment, the application of lessons learned to future projects, the documentation of the impact of change requests, the updating and modification of project plans and documents or the portfolio composition, etc., achieve better performance for their projects, programs, and portfolios than the PBFs that do not run these routines.

\subsection{Implications for Managers and Policy Makers}

The theoretical claims of this study may help project and executive managers to enhance their understanding on the relationship between project capabilities and the performance at both the project and organizational levels. We provide project managers with three types of routines that are the micro-foundations of project dynamic capabilities and thus should be applied to manage projects in unstable and dynamic environments. On the one hand, project managers need to sense the project environment in a search for uncertainties and risks. On the other hand, our theoretical framework aims for a commitment to a stronger customer orientation in PBFs, as several researchers have suggested [65]. Since the capacity of stakeholders to influence project and project management processes changes during the project lifecycle, there is a growing need for a dynamic stakeholder management $[56,65,66]$. Our theoretical framework shows that project managers should continually sense stakeholders' influence to determine when and how to manage stakeholders' claims. Finally, project managers should not get stuck in the original plan. Although planning is a necessary activity, project managers must be aware that some constraints and events cannot be acknowledged at project initiation [55]. Thus, project plans need to incorporate a degree of flexibility to allow for modifications, even to the point of reevaluating project goals and the modification of the project team [67].

Our theoretical framework highlights the new role that projects play within firm strategy as the vehicles for implementing changes and even as strategic elements that generate economic value and have the potential to become a source of competitive advantages. Therefore, the management team should acknowledge projects as potential sources of both organizational capabilities and business models with a bottom-up effect. Moreover, our theoretical framework provides several insights for reaching organizational strategic goals through project implementation. On the one hand, the management team needs to sense the project-layer routines and project knowledge acquired during project implementation that could be exploited in subsequent projects. In addition, the management team should sense the opportunities that past projects offer (e.g., the creation of new markets or the 
development of improved technologies). On the other hand, after running the routines of PBF-layer sensing and seizing, executive managers should decide on the nature of the future portfolio and which of the routines that were run in past projects should be turned into organizational capabilities.

Our theoretical framework also has several implications for policy makers since the public sector allocates a great amount of public funds to projects, either directly, through public infrastructure projects, or indirectly, through public policies that foster innovation. It is crucial that policy-makers understand the relationship between projects, portfolios, and the overall organizational strategy, hence supporting the projects that are actually aligned to strategic objectives and closing down those that are not, even if it is costly in political terms. Moreover, they should introduce several clauses in public tenders, forcing winning companies to properly deploy some of the sensing-seizing-transforming routines like, for example, documenting their lessons learned in order to create a knowledge silo accessible for subsequent projects.

\subsection{Contributions to the Body of Knowledge}

We offer a solution for the so-called PBF dilemma that highlights the internal tension between the temporary nature of projects and the long-term perspective of the permanent organization $[1,68]$. In this sense, the focus of projects is short term and results driven, whereas the focus of the overall $\mathrm{PBF}$ is long term and mission driven [1]. The literature suggests that building project capabilities and promoting project learning can overcome the PBF dilemma. The routines described at the PBF layer of our theoretical framework shed light both on building dynamic capabilities and on the achievement of overall PBF success through the implementation of multiple projects.

Finally, as a future avenue for research, our theoretical framework might be used for shedding some light on PBF ambidexterity. Previous studies posit that PBFs achieve ambidexterity by performing two different types of projects: innovative projects, which are focused on exploration, and routine projects, which are focused on exploitation [41]. Therefore, this line of research shows that PBFs possess structural ambidexterity and executive managers decide when to launch each type of project. Our theoretical framework relies on contextual ambidexterity because we propose that project managers dynamically decide when to deploy sensing (exploring) or seizing (exploiting) routines within the same project. Thus, PBFs can be ambidextrous without a physical separation of exploration and exploitation into different project implementation methods. Furthermore, our theoretical framework might shed light on the organizational tensions arising when deciding how to allocate resources between the exploration and exploitation activities [69]. The supposed trade-off between explorative and exploitative capacities is smoothed in our theoretical framework since we do not present exploring and exploiting capacities as separate processes but as two parts of the same dynamic capability.

Author Contributions: Conceptualization, V.H. and N.M.-C.; formal analysis, V.H. and N.M.-C.; writing-original draft preparation, V.H.; writing-review and editing, V.H.; supervision, N.M.-C.; funding acquisition, N.M.-C. All authors have read and agreed to the published version of the manuscript.

Funding: This research was funded by Ministerio de Ciencia e Innovación a través del Programa Estatal de Fomento de la Investigación Científica y Técnica de Excelencia, grant number ECO2016-78128-P.

Conflicts of Interest: The authors declare no conflict of interest.

\section{References}

1. Melkonian, T.; Picq, T. Building Project Capabilities in PBOs: Lessons from the French Special Forces. Int. J. Proj. Manag. 2011, 29, 455-467. [CrossRef]

2. Thiry, M.; Deguire, M. Recent developments in project-based organisations. Int. J. Proj. Manag. 2007, 25, 649-658. [CrossRef]

3. Hanisch, B.; Wald, A. Effects of complexity on the success of temporary organizations: Relationship quality and transparency as substitutes for formal coordination mechanisms. Scand. J. Manag. 2014, 30, $197-213$. [CrossRef] 
4. Hobday, M. The project-based organisation: An ideal form for managing complex products and systems? Res. Policy 2000, 29, 871-893. [CrossRef]

5. Chandler, A.D. Organizational capabilities and the economic history of the industrial enterprise. J. Econ. Perspect. 1992, 6, 79-100. [CrossRef]

6. Makadok, R. Toward a synthesis of the resource-based and dynamic-capability views of rent creation. Strateg. Manag. J. 2001, 22, 387-401. [CrossRef]

7. Davies, A.; Brady, T. Organisational capabilities and learning in complex product systems: Towards repeatable solutions. Res. Policy 2000, 29, 931-953. [CrossRef]

8. Jugdev, K.; Mathur, G.; Fung, T.S. Project management assets and their relationship with the project management capability of the firm. Int. J. Proj. Manag. 2007, 25, 560-568. [CrossRef]

9. Petit, Y. Project portfolios in dynamic environments: Organizing for uncertainty. Int. J. Proj. Manag. 2012, 30, 539-553. [CrossRef]

10. Winch, G.; Leiringer, R. Owner project capabilities for infrastructure development: A review and development of the "strong owner" concept. Int. J. Proj. Manag. 2016, 34, 271-281. [CrossRef]

11. Winter, S.G. Understanding dynamic capabilities. Strateg. Manag. J. 2003, 24, 991-995. [CrossRef]

12. Zahra, S.A.; Sapienza, H.J.; Davidsson, P. Entrepreneurship and Dynamic Capabilities: A Review, Model and Research Agenda. J. Manag. Stud. 2006, 43, 917-955. [CrossRef]

13. Engwall, M. No project is an island: Linking projects to history and context. Res. Policy 2003, 32, 789-808. [CrossRef]

14. Turner, J.R.; Müller, R. On the nature of the project as a temporary organization. Int. J. Proj. Manag. 2003, 21, 1-8. [CrossRef]

15. Tikkanen, H.; Kujala, J.; Artto, K. The marketing strategy of a project-based firm: The Four Portfolios Framework. Proj. Mark. Mark. Solut. 2007, 36, 194-205. [CrossRef]

16. Turner, J.R.; Keegan, A. The management of operations in the project-based organisation. J. Chang. Manag. 2000, 1, 131-148. [CrossRef]

17. Di Vincenzo, F.; Mascia, D. Social capital in project-based organizations: Its role, structure, and impact on project performance. Int. J. Proj. Manag. 2012, 30, 5-14. [CrossRef]

18. Lindkvist, L. Governing project-based firms: Promoting market-like processes within hierarchies. J. Manag. Gov. 2004, 8, 3-25. [CrossRef]

19. Turkulainen, V.; Kujala, J.; Artto, K.; Levitt, R.E. Organizing in the context of global project-based firm-The case of sales-operations interface. Manag. Key Supplier Relatsh. 2013, 42, 223-233. [CrossRef]

20. Söderlund, J.; Tell, F. The P-form organization and the dynamics of project competence: Project epochs in Asea/ABB, 1950-2000. Int. J. Proj. Manag. 2009, 27, 101-112. [CrossRef]

21. Whitley, R. Project-based firms: New organizational form or variations on a theme? Ind. Corp. Chang. 2006, 15, 77-99. [CrossRef]

22. Gareis, R. Management by projects: The management strategy of the 'new' project-oriented company. Int. J. Proj. Manag. 1991, 9, 71-76. [CrossRef]

23. Boh, W.F. Mechanisms for sharing knowledge in project-based organizations. Inf. Organ. 2007, 17, $27-58$. [CrossRef]

24. Morris, P.W.G.; Jamieson, A. Moving from corporate strategy to project strategy. Proj. Manag. J. 2005, 36, 5-18. [CrossRef]

25. Brady, T.; Davies, A. Building project capabilities: From exploratory to exploitative learning. Organ. Stud. 2004, 25, 1601-1621. [CrossRef]

26. Hayes, R.H.; Wheelwright, S.C.; Clark, K.B. Dynamic Manufacturing: Creating the Learning Organization; The Free Press: New York, NY, USA, 1988.

27. Frederiksen, L.; Davies, A. Vanguards and ventures: Projects as vehicles for corporate entrepreneurship. Int. J. Proj. Manag. 2008, 26, 487-496. [CrossRef]

28. Mutka, S.; Aaltonen, P. The impact of a delivery project's business model in a project-based firm. Int. J. Proj. Manag. 2013, 31, 166-176. [CrossRef]

29. Vuori, E.; Artto, K.; Sallinen, L. Investment project as an internal corporate venture. Int. J. Proj. Manag. 2012, 30, 652-662. [CrossRef]

30. Karlsen, J.T.; Gottschalk, P. Factors Affecting Knowledge Transfer in IT Projects. Eng. Manag. J. 2004, 16, 3-11. [CrossRef] 
31. Kotnour, T.; Vergopia, C. Learning-Based Project Reviews: Observations and Lessons Learned from the Kennedy Space Center. Eng. Manag. J. 2005, 17, 30-38. [CrossRef]

32. Mueller, J. A specific knowledge culture: Cultural antecedents for knowledge sharing between project teams. Eur. Manag. J. 2014, 32, 190-202. [CrossRef]

33. Prencipe, A.; Tell, F. Inter-project learning: Processes and outcomes of knowledge codification in project-based firms. Res. Policy 2001, 30, 1373-1394. [CrossRef]

34. Zhai, X.F.; Liu, A.M.M.; Fellows, R. Role of human resource practices in enhancing organizational learning in Chinese construction organizations. J. Manag. Eng. 2013, 30, 194-204. [CrossRef]

35. Levitt, R.E.; Wang, C.-M.A.; Ho, S.P.; Javernick-Will, A. Encouraging knowledge sharing in engineering firms-part II: Game theory analysis and firm strategies. Eng. Proj. Organ. J. 2013, 3, 22-31. [CrossRef]

36. Turner, J.R.; Keegan, A. Mechanisms of governance in the project-based organization: Roles of the broker and steward. Eur. Manag. J. 2001, 19, 254-267. [CrossRef]

37. Jugdev, K.; Thomas, J. Project management maturity models: The silver bullets of competitive advantage. Proj. Manag. J. 2002, 33, 4-14. [CrossRef]

38. Lee, L.S.; Anderson, R.M. An exploratory investigation of the antecedents of the IT project management capability. e-Service J. 2006, 5, 27-42. [CrossRef]

39. Hermano, V.; Martín-Cruz, N. The role of top management involvement in firms performing projects: A dynamic capabilities approach. J. Bus. Res. 2016, 69, 3447-3458. [CrossRef]

40. Biedenbach, T.; Müller, R. Absorptive, innovative and adaptive capabilities and their impact on project and project portfolio performance. Int. J. Proj. Manag. 2012, 30, 621-635. [CrossRef]

41. Davies, A.; Brady, T. Explicating the dynamics of project capabilities. Int. J. Proj. Manag. 2016, 34, $314-327$. [CrossRef]

42. Choi, S.; Cho, I.; Han, S.H.; Kwak, Y.H.; Chih, Y.Y. Dynamic Capabilities of Project-Based Organization in Global Operations. J. Manag. Eng. 2018, 34, 4018027. [CrossRef]

43. Hansen, D.; Møller, N. Conceptualizing Dynamic Capabilities in Lean Production: What are They and How Do They Develop? Eng. Manag. J. 2016, 28, 194-208. [CrossRef]

44. Killen, C.P.; Hunt, R.A. Dynamic capability through project portfolio management in service and manufacturing industries. Int. J. Manag. Proj. Bus. 2010, 3, 157-169. [CrossRef]

45. Killen, C.P.; Jugdev, K.; Drouin, N.; Petit, Y. Advancing project and portfolio management research: Applying strategic management theories. Int. J. Proj. Manag. 2012, 30, 525-538. [CrossRef]

46. Pereira, D.; Leitão, J. Absorptive capacity, coopetition and generation of product innovation: Contrasting Italian and Portuguese manufacturing firms. Int. J. Technol. Manag. 2016, 71, 10-37. [CrossRef]

47. Martin-de Castro, G. Knowledge management and innovation in knowledge-based and high-tech industrial markets: The role of openness and absorptive capacity. Ind. Mark. Manag. 2015, 47, 143-146. [CrossRef]

48. Gutiérrez Rodríguez, A.J.; Barón, N.J.; Guaita Martínez, J.M. Validity of Dynamic Capabilities in the Operation Based on New Sustainability Narratives on Nature Tourism SMEs and Clusters. Sustainability 2020, 12, 1004. [CrossRef]

49. Teece, D.J. Explicating dynamic capabilities: The nature and microfoundations of (sustainable) enterprise performance. Strateg. Manag. J. 2007, 28, 1319-1350. [CrossRef]

50. Teece, D.J. Dynamic Capabilities and Strategic Management: Organizing for Innovation and Growth; Blackwell Publishing: Malden, MA, USA, 2009.

51. Helfat, C.E.; Peteraf, M.A. Understanding dynamic capabilities: Progress along a developmental path. Strateg. Organ. 2009, 7, 91-102. [CrossRef]

52. Helfat, C.E.; Winter, S.G. Untangling dynamic and operational capabilities: Strategy for the (N) ever-changing world. Strateg. Manag. J. 2011, 32, 1243-1250. [CrossRef]

53. Eisenhardt, K.M.; Martin, J.A. Dynamic capabilities: What are they? Strateg. Manag. J. 2000, $21,1105-1121$. [CrossRef]

54. Vanpoucke, E.; Vereecke, A.; Wetzels, M. Developing supplier integration capabilities for sustainable competitive advantage: A dynamic capabilities approach. J. Oper. Manag. 2014, 32, 446-461. [CrossRef]

55. Hermano, V.; Martin-Cruz, N. Expanding the knowledge on project maangement standards: A look into the PMBOK with dynamic lenses. In Project Management and Engineering Research; Ayuso, J.L., Yagüe, J.L., Capuz-Rizo, S., Eds.; Springer International Publishing: Cham, Switzerland, 2019; pp. 19-34. 
56. Aaltonen, K.; Kujala, J. A project lifecycle perspective on stakeholder influence strategies in global projects. Scand. J. Manag. 2010, 26, 381-397. [CrossRef]

57. Petit, Y.; Hobbs, B. Project portfolios in dynamic environments: Sources of uncertainty and sensing mechanisms. Proj. Manag. J. 2010, 41, 46-58. [CrossRef]

58. Leonard, D. Core capabilities and core rigidities: A paradox in managing new product development. Strateg. Manag. J. 1992, 13, 111-125. [CrossRef]

59. Prusak, L. Knowledge in Organizations; Butterworth-Heinemann: Newtown, MA, USA, 1997.

60. Voss, M. Impact of customer integration on project portfolio management and its success-Developing a conceptual framework. Int. J. Proj. Manag. 2012, 30, 567-581. [CrossRef]

61. Levinthal, D.A.; March, J.G. The myopia of learning. Strateg. Manag. J. 1993, 14, 95-112. [CrossRef]

62. Bastanchury-López, M.T.; De-Pablos-Heredero, C.; Montes-Botella, J.L.; Martin-Romo-Romero, S.; Garcia, A. Impact of Dynamic Capabilities on Performance in Dairy Sheep Farms in Spain. Sustainability 2020, 12, 3368. [CrossRef]

63. Peteraf, M.; Di Stefano, G.; Verona, G. The elephant in the room of dynamic capabilities: Bringing two diverging conversations together. Strateg. Manag. J. 2013, 34, 1389-1410. [CrossRef]

64. Teece, D.J.; Pisano, G.; Shuen, A. Dynamic capabilities and strategic management. Strateg. Manag. J. 1997, 18, 509-533. [CrossRef]

65. Perminova, O.; Gustafsson, M.; Wikström, K. Defining uncertainty in projects-a new perspective. Int. J. Proj. Manag. 2008, 26, 73-79. [CrossRef]

66. Pollack, J. The changing paradigms of project management. Int. J. Proj. Manag. 2007, 25, 266-274. [CrossRef]

67. Scott-Young, C.; Samson, D. Project success and project team management: Evid. from capital projects in the process industries. J. Oper. Manag. 2008, 26, 749-766. [CrossRef]

68. Sydow, J.; Lindkvist, L.; DeFillippi, R. Project-based organizations, embeddedness and repositories of knowledge: Editorial. Organ. Stud. 2004, 25, 1475. [CrossRef]

69. Peng, M.Y.-P.; Zhang, Z.H.; Yen, H.-Y.; Yang, S.-M. Dynamic Capabilities and Firm Performance in the High-Tech Industry: Quadratic and Moderating Effects under Differing Ambidexterity Levels. Sustainability 2019, 11, 5004. [CrossRef] 